\title{
Statistical analysis of measured operators' finger doses in interventional radiology
}

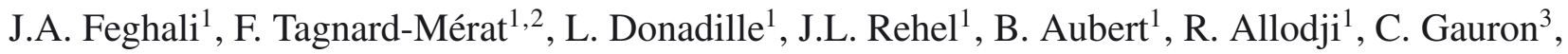 \\ J. Farah ${ }^{1 \mathrm{a}}$ and I. Clairand ${ }^{1}$ \\ 1 IRSN, Pôle Radioprotection Homme, BP 17, 92262 Fontenay-aux-Roses, France. \\ 2 Service de Médecine de Prévention du Ministère de la Défense, Centre de Médecine Prévention des Armées de Paris/EHMP site de Paris 5, \\ 74 boulevard de Port-Royal, 75230 Paris Cedex 05, France. \\ 3 INRS, Département EAM, 75680 Paris Cedex 14, France.
}

Received 27 May 2013 - Accepted 16 September 2013

\begin{abstract}
This work suggests a classification of interventional radiology and cardiology procedures based on statistical analysis of operators' finger doses measured in routine clinical conditions. In total, 346 finger doses were measured and the observed mean finger dose per class of procedure ranged from $0.03 \mathrm{mSv}$ to $1.56 \mathrm{mSv}$ for Cerebral, and Bone and Joint procedures, respectively. The statistical analysis showed that the finger dose in Cerebral procedures is significantly lower than in Cardiac procedures, which was significantly lower than the rest. Furthermore, finger doses in therapeutic procedures and in close ones were significantly greater than in diagnostic procedures and in distal ones. This work also studied the statistical relation between the use of ceiling-suspended shields or leaded gloves and the extremity dose. From the set of collected and analyzed data, a finger dose classification was proposed for different criteria: procedure type (diagnostics/therapeutic), proximity (close/distal), procedure class and access route.
\end{abstract}

Keywords: interventional radiology / operator finger dose / statistical analysis / procedure classification

\section{Introduction}

Interventional radiology (IR) procedures use X-ray images in order to guide small devices (catheters, balloons, stents, etc.) through blood vessels, thus presenting many advantages when compared with surgical procedures, such as minimal invasiveness, lower cost and reduced hospital stay (Miller, 2008). The use of this technique has increased throughout the world over the past 20 years and new IR procedures are being introduced with the development of devices, techniques and indications (Togni et al., 2004; UNSCEAR, 2008; Roger et al., 2011; etc.). However, since operators are generally standing near the patient during the procedure, their level of exposure is an important matter of concern (Whitby and Martin, 2005; Kim and Miller, 2009; Miller et al., 2010; etc.). In particular, operators' hands can receive high doses as they are generally not well protected from the scattered X-ray field by collective protective equipment (e.g. ceiling shields) and prone to intercept the primary X-ray beam repeatedly (Carinou et al., 2011). Besides, the use of leaded gloves is not recommended due to its low cost-to-benefit ratio and the fact that, in this case, hands should strictly be kept out of the primary beam (Vaňo et al., 1995; Martin, 2009; Miller et al., 2010). Finally, hand exposure is

\footnotetext{
a jad.farah@irsn.fr
}

related to many different factors that come from the four concepts in basic radiation protection: time, distance, shielding and intensity of X-rays.

The factors that affect operators' exposure levels are mainly: the complexity and type of the procedure, the fluoroscopy time, the patient's body habitus (body build and constitution), the operator's skills and training experience (Ramsdale et al., 1990; Watson et al., 1997; Delichas et al., 2003; etc.), the access route and tube position, i.e. distance (Martin, 2009; Carinou et al., 2011; etc.), the use of collective and personal protective tools (Kim and Miller, 2009; Carinou et al., 2011, etc.), and equipment performance, which is mainly related to the technical parameters of the X-ray tube such as current intensity $(\mathrm{mA})$, voltage $(\mathrm{kV})$, collimation and filtration (intensity of X-rays) (Delichas et al., 2003). These technical parameters and the fluoroscopy time are included in the DoseArea Product (DAP), which is available on most current installations in IR. Previous studies have thus quantified finger doses for interventional radiologists and cardiologists (Whitby and Martin, 2005; Efstathopoulos et al., 2011); however, none has considered the use of statistical analysis to scale exposure levels and classify interventional procedures.

The purpose of this study was threefold: (i) evaluate the range of finger doses received in different classes of procedures, (ii) investigate the influence of the above cited factors 
on the finger dose in a rigorous manner, and (iii) classify the procedures, based on statistical analysis, according to a dose scale.

\section{Materials and Methods}

\subsection{Description of the study}

The European ORAMED project (Optimization of RAdiation protection of MEDical staff, 2008-2011) (Vanhavere et al., 2012) included a wide measurement campaign conducted in eight French hospitals to assess the extremity dose in clinical interventional radiology settings. Measurements of exposure levels were made with no specific dose-reduction effort requested, nor undertaken, and no instructions regarding the use of radiation protection devices. The studied procedures covered several medical specialized areas including cardiology, vascular, orthopedics, neurology, etc. These were selected considering the potential impact on the annual exposure of the staff, i.e. high annual frequency and possible high DAP values. To the extent possible, one physician specialist per type of procedure was followed for at least ten procedures representative of his usual clinical activity with a total of 41 experienced operators followed. According to the study of Whitby and Martin (2005), and for a mix of IR procedures, the most exposed region is considered to be the one extending from the little to the middle fingers of the closest hand to the X-ray scattering center (usually the left one). Thus, the dosimeter was taped on the nail tip of the middle finger of the most exposed hand (usually the left hand). Each of the eight hospitals received a set of 20 dosimeters, including 5 background dosimeters, to be used for two months. After the two-month period, the dosimeters were sent back to be read and zeroed, then sent to the same hospitals for a new set of measurements.

For each procedure a survey was filled out by a local identified Radiation Safety Officer (RSO) to provide information regarding the: name of the hospital, angiographic equipment models and their associated dose reduction features, identification of the operator, nature and total fluoroscopy time of the procedure, access route, proximity, orientation of the X-ray tube, use of protective tools, and DAP. The proximity parameter was introduced to take into account both the explored patient's region and the access route. A procedure is considered close when the hands have a significant chance of intercepting the primary beam during fluoroscopy sequences and distal if the distance between the closest hand and the center of the region explored is the same length as, or longer than, the diameter of the region explored. To analyze finger doses, procedures were classified according to the anatomical regions explored since, for some organs, there is an overlap in specialty (Miller, 2008). Eight classes were thus identified: Cerebral, Cardiac, Thoracic, Upper-extremity, Abdominal, Pelvic, Lower-extremity, and Bone and Joints. Thoracic and Cardiac procedures were differentiated, being done by different specialists. The angiographic equipment models were fairly comparable in each of the eight hospitals, with the newest systems mainly operating in neurology. Table 1 gives an overview of measurement conditions including classes and number of procedures, main diagnostic and therapeutic procedures, number of operators and hospitals, and use of protection equipment.

\subsection{Dosimeters: type, calibration and uncertainty estimation}

Finger doses were measured using thermoluminescent dosimeters (TLD) of Harshaw type TLD-700H (7LiF:Mg, $\mathrm{Cu}, \mathrm{P}$ ). These were calibrated according to the skin dose equivalent, $\mathrm{H}_{\mathrm{p}}(0.07)$ (ICRP, 1997), on an ISO rod phantom representing the finger (ISO, 1999). Their energy, dose equivalent and angular responses were characterized in reference ISO photon fields (ISO, 1996) and using appropriate ISO conversion coefficients (ISO, 1999). The energy response is shown in Figure 1, from $33 \mathrm{keV}$ (ISO X-ray field N-40) to $662 \mathrm{keV}$ (ISO S-Cs field), where filled symbols represent ISO fields used for this calibration. Most of the X-ray fields encountered in IR have spectra compatible with those between ISO (1997) X-ray fields W-60 and W-110 (mean energies equal to 45 and $79 \mathrm{keV}$, respectively). Therefore, the calibration coefficient used for all measurements was chosen as the mean of the calibration coefficients determined for W-60 and W-110 fields. The lower detection limit (LDL) was set to $20 \mu \mathrm{Sv}$ and any measured $\mathrm{H}_{\mathrm{p}}(0.07)$ below the LDL was set equal to it. Finally, no correction was applied to account for angular effects since the angular response of TLDs between $0^{\circ}$ and $90^{\circ}$ (relative to $0^{\circ}$ ) remained larger than 0.91 and this under-response is partially compensated for by the over-response at low dose.

The relative uncertainty of the calibration coefficient was estimated, at one standard deviation, to be equal to $14 \%$ for the following components: the reference dose equivalent $(2.4 \%)$, the TLD repeatability $(3.5 \%)$ and TLD set homogeneity $(3.6 \%)$. To take into account the energy response variation between 1.14 and 0.86 for W-60 and W-110 fields, a uniform distribution was assumed between these two points, leading to an additional $8.1 \%$ uncertainty component. The same assumption was made to account for variations between 1.34 and 1 of the relative dose response and between 1 and 0.91 of the relative angular response, leading to additional $9.8 \%$ and $2.6 \%$ components, respectively. For each individual measurement associated with an IR procedure, the background subtraction leads to an additional uncertainty due to the fluctuations of the 5 background dosimeters. The lower the dose, the larger the relative contribution of this component becomes. Hence, the total relative uncertainty on any single measurement can be on average summarized as follows: $50 \%$ if the $H_{\mathrm{p}}(0.07)$ measurement is $20 \mu \mathrm{Sv}$, dominated by background fluctuations; $20 \%$ for $50 \mu \mathrm{Sv} ; 17 \%$ for $100 \mu \mathrm{Sv}$ and $15 \%$ beyond $500 \mu \mathrm{Sv}$. The latter uncertainty is almost equivalent to the asymptotic $14 \%$ calibration coefficient uncertainty.

\subsection{Statistical Analysis}

ORAMED finger dose data was analyzed using the SAS ${ }^{\circledR}$ statistical analysis tool (SAS Institute Inc., 1999). The hypothesis of normality, needed for parametric tests such as the Student t-test (Pappas and DePuy, 2004), concerning the distributions of both the dose and its natural logarithm was investigated ( $c f$. Fig. 2). According to Figure $2 b$ the natural logarithm of the dose was found to be compatible with a normal distribution. Consequently, when the sample size was sufficient 
Table 1. Data populations for each of the 8 procedure classes considered and information on operators and the use of protection equipment.

\begin{tabular}{|c|c|c|c|c|c|c|c|c|}
\hline \multirow{2}{*}{$\begin{array}{l}\text { Class of } \\
\text { procedures }\end{array}$} & \multirow{2}{*}{$\begin{array}{c}\begin{array}{c}\text { Number } \\
\text { of } \\
\text { procedures }\end{array} \\
\end{array}$} & \multicolumn{2}{|c|}{ Type of procedure } & \multirow{2}{*}{$\begin{array}{l}\text { Number } \\
\text { of operators } \\
\text { (hospitals }\end{array}$} & \multicolumn{4}{|c|}{ Use of protection equipment } \\
\hline & & Diagnostic & Therapeutic & & $\begin{array}{c}\text { Leaded } \\
\text { gloves }\end{array}$ & $\begin{array}{l}\text { Ceiling- } \\
\text { suspended } \\
\text { shield } \\
\end{array}$ & $\begin{array}{l}\text { Table } \\
\text { shield }\end{array}$ & None/NA \\
\hline Cerebral & 8 & Arteriography & Brain AVM embolization & $1(1)$ & 1 & 7 & 7 & 1 \\
\hline Cardiac & 75 & Coronarography & $\begin{array}{l}\text { Coronary angioplasty } \\
\text { Defibrillator implantation } \\
\text { Pacemaker implantation }\end{array}$ & $14(6)$ & 2 & 53 & 56 & 17 \\
\hline Thoracic & 19 & $\begin{array}{l}\text { Pulmonary } \\
\text { angiography }\end{array}$ & $\begin{array}{l}\text { Bronchial embolization } \\
\text { Stent implantation } \\
\text { Endoplasty } \\
\text { Vena cava filter } \\
\text { placement/removal } \\
\text { Catheter implantation }\end{array}$ & $12(5)$ & 0 & 4 & 8 & 11 \\
\hline $\begin{array}{l}\text { Upper- } \\
\text { extremity }\end{array}$ & 10 & $\begin{array}{l}\text { Fistulography } \\
\text { Arteriography }\end{array}$ & $\begin{array}{c}\text { Arteriovenous fistula } \\
\text { Fistulography + Angioplasty } \\
\text { AVM embolization }\end{array}$ & $5(2)$ & 3 & 4 & 5 & 5 \\
\hline Abdominal & 142 & $\begin{array}{l}\text { Hepatic biopsy } \\
\text { kidney biopsy } \\
\text { Cholangiography }\end{array}$ & $\begin{array}{l}\text { Hepatic chemoembolization } \\
\text { Biliary drainage (and stenting) } \\
\text { Renal arteriography } \\
\text { and Angioplasty } \\
\text { Abdominal stent graft } \\
\text { Gastrostomy }\end{array}$ & $23(7)$ & 0 & 17 & 75 & 65 \\
\hline Pelvic & 21 & $\begin{array}{l}\text { Control of iliac } \\
\text { fibrinolysis }\end{array}$ & $\begin{array}{c}\text { Iliac angioplasty } \\
\text { Pelvic embolization } \\
\text { Pelvic stent }\end{array}$ & $11(4)$ & 0 & 4 & 13 & 8 \\
\hline $\begin{array}{l}\text { Lower- } \\
\text { extremity }\end{array}$ & 30 & Arteriography & $\begin{array}{c}\text { Arteriography + Angioplasty } \\
\text { AVM embolization }\end{array}$ & $5(2)$ & 0 & 8 & 11 & 18 \\
\hline $\begin{array}{l}\text { Bone } \\
\text { and Joint }\end{array}$ & 41 & $\begin{array}{l}\text { Vertebral biopsy } \\
\text { Myelography }\end{array}$ & $\begin{array}{l}\text { Vertebroplasty } \\
\text { Spine injections } \\
\text { Vertebral biopsy } \\
\text { Discography }\end{array}$ & $3(3)$ & 21 & 13 & 13 & 27 \\
\hline
\end{tabular}

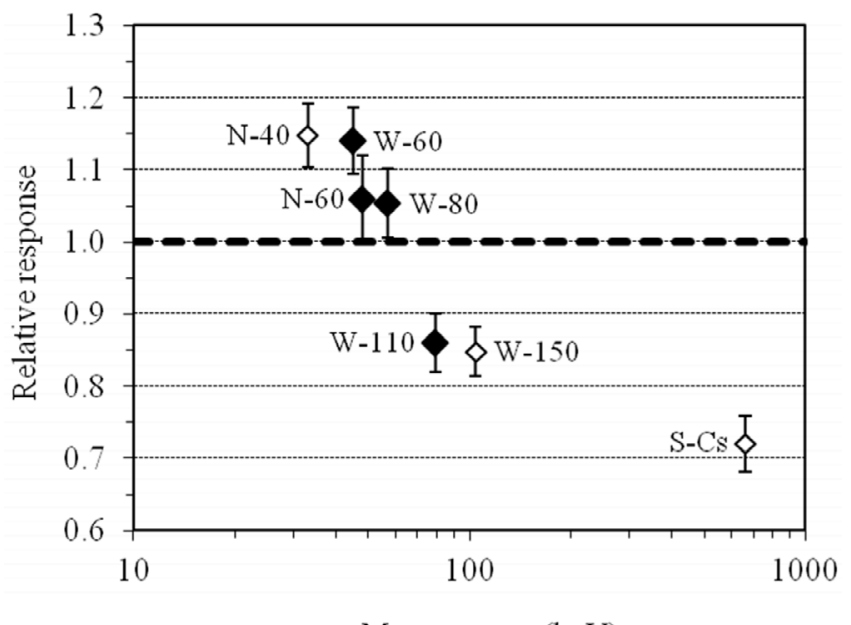

Mean energy (keV)

Fig. 1. Energy response relative to the mean response between ISO $\mathrm{N}-40$ and S-Cs fields.

$(n>30)$, the parametric Student t-test (hereafter noted ttest) was applied to the natural logarithm of the dose to compare the means and then the Wilcoxon rank-sum test (hereafter noted WRS test) was applied to compare the medians (Fay and Proschan, 2010). However, when the sample size was small, only the WRS test was applied to compare the medians. For all the statistical tests, a result was considered significant for $p<0.05$. For $n>30$, this criterion applied to both the t-test and WRS test analyses.

These tests were used to investigate the difference in dose among the different classes of procedures and to study the influence of the following factors: access route, X-ray field proximity, use of personal and collective protection equipment, X-ray tube orientation, fluoroscopy time, and DAP. As already mentioned (Donadille et al., 2011), these analyses are difficult since, when real procedures are monitored, the different factors influencing the dose vary simultaneously. Hence, this tends to attenuate the effect of an analyzed factor, such as the protection equipment, with respect to what would be theoretically expected.

\section{Results and discussion}

\subsection{Finger dose measurement and distribution}

Table 2 gives general dose distribution information per procedure for the 8 anatomical classes. Tables 3 and 4 document the radiation dose as a function of procedure type to separate between the diagnostic and therapeutic nature of 

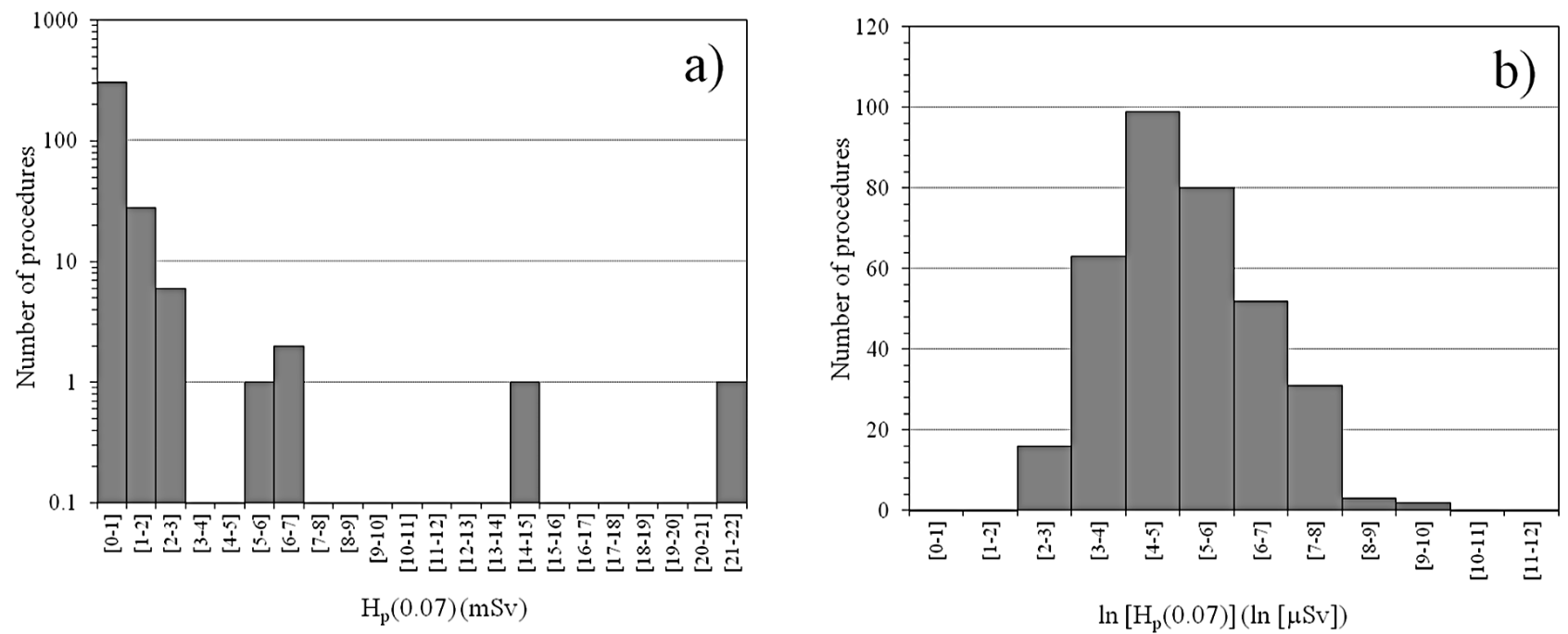

Fig. 2. Histograms of the dose (a) (in $\mathrm{mSv}$ ) and of its natural logarithm (b) (in $\ln [\mu \mathrm{Sv}]$ ). The bin intervals in abscissa are given in square brackets.

Table 2. Mean DAP, fluoroscopy time and finger doses for each class of procedures.

\begin{tabular}{|c|c|c|c|c|c|c|c|}
\hline \multirow{2}{*}{$\begin{array}{l}\text { Class of } \\
\text { procedures }\end{array}$} & \multirow{2}{*}{$\begin{array}{l}\text { Mean DAP } \\
\left(\mathbf{m G y} \cdot \mathrm{cm}^{2}\right)\end{array}$} & \multirow{2}{*}{$\begin{array}{c}\text { Mean fluoroscopy } \\
\text { time (min) }\end{array}$} & \multicolumn{5}{|c|}{$H_{\mathrm{p}}(\mathbf{0 . 0 7})(\mathrm{mSv})$} \\
\hline & & & Mean & SD & Median & Minimum & Maximum \\
\hline Cerebral & 404173 & 57 & 0.03 & 0.01 & 0.02 & $\leqslant 0.02$ & 0.06 \\
\hline Cardiac & 33872 & 10 & 0.17 & 0.26 & 0.09 & 0.02 & 1.98 \\
\hline Thoracic & 102164 & 12 & 0.41 & 0.47 & 0.15 & 0.05 & 1.51 \\
\hline Upper-extremity & 41980 & 19 & 0.58 & 0.84 & 0.36 & 0.025 & 2.87 \\
\hline Abdominal & 156857 & 21 & 0.38 & 0.81 & 0.14 & $\leqslant 0.02$ & 6.81 \\
\hline Pelvic & 57256 & 15 & 0.63 & 0.49 & 0.45 & 0.044 & 1.54 \\
\hline Lower-extremity & 160577 & 16 & 0.51 & 0.51 & 0.30 & $\leqslant 0.02$ & 1.76 \\
\hline Bone and Joint & 118446 & 11 & 1.56 & 4.09 & 0.13 & $\leqslant 0.02$ & 22.0 \\
\hline
\end{tabular}

procedures. Descriptive finger dose statistics (mean, standard deviation (SD), median, minimum \& maximum) are provided; specific data are also given for measurements with a sample size $\geqslant 10$. Tables 3 and 4 also include information on the access route (femoral, radial, internal jugular vein; IJV, subclavian, iliofemoral, direct) and on the operator-tube proximity (close, distal). To ease the comparison between the different dose levels recorded for each procedure, fluoroscopy time and DAP (Dose Area Product) information were provided whenever available. From these tables, it is clear that the distributions generally exhibit large SDs relative to the mean doses, and significant differences between mean and median values are also observed. This reflects a large spread and asymmetry commonly reported in the literature (Kim et al., 2008; Martin 2009; Carinou et al., 2011).

\subsection{Influence of exposure conditions}

\subsubsection{Effect of procedure type}

Measurements showed significantly greater median finger dose values for therapeutic procedures (sample size $n=262$, median dose $0.23 \mathrm{mSv}$ ) than for diagnostic procedures $(n=84,0.16 \mathrm{mSv})$. The highest doses are seen for therapeutic close procedures, i.e. spine injection, arteriovenous fistula, pelvic embolization and biliary drainage. Moreover, when compared with diagnostic procedures, therapeutic ones have a significantly higher mean DAP value $\left(170646 \mathrm{mGy} . \mathrm{cm}^{2}\right.$ against $62656 \mathrm{mGy} . \mathrm{cm}^{2}$ for diagnostic procedures) and are significantly longer, with a mean fluoroscopy time of $26 \mathrm{~min}$ against 4 min for diagnostic procedures.

\subsubsection{Effect of proximity}

The proximity parameter was introduced to separate between procedures where the hands have a significant chance of intercepting the primary beam during fluoroscopy sequences (close) and those where such a situation is not possible (distal). From Tables 3 and 4, the median registered dose for close procedures ( $n=123,0.25 \mathrm{mSv}$ ) was found to be significantly greater than that for distal procedures $(n=223,0.11 \mathrm{mSv})$. This result is in total agreement with expectations and with previous studies (Whitby and Martin, 2005; Blanpain et al., 2008; Donadille et al., 2011). 
Table 3. Finger doses for different diagnostic procedures; specific data are given for measurements with a sample size $\geqslant 10$.

\begin{tabular}{|c|c|c|c|c|c|c|c|c|c|c|c|}
\hline \multirow{2}{*}{$\begin{array}{l}\text { Class of } \\
\text { procedures }\end{array}$} & \multirow{2}{*}{$\begin{array}{c}\text { Type of } \\
\text { procedures }\end{array}$} & \multirow{2}{*}{$\begin{array}{c}\text { Number } \\
\text { of } \\
\text { procedures }\end{array}$} & \multirow{2}{*}{$\begin{array}{c}\text { Access } \\
\text { route } \\
\text { (number) }\end{array}$} & \multirow[b]{2}{*}{ Proximity } & \multirow{2}{*}{$\begin{array}{c}\text { Mean } \\
\text { DAP } \\
\left(\mathrm{mGy} . \mathrm{cm}^{2}\right)\end{array}$} & \multirow{2}{*}{$\begin{array}{c}\text { Mean } \\
\text { fluoroscopy } \\
\text { time (min) }\end{array}$} & \multicolumn{5}{|c|}{$H_{\mathrm{p}}(0.07)(\mathrm{mSv})$} \\
\hline & & & & & & & Mean & SD & Median & Minimum & Maximum \\
\hline Cerebral & All & 1 & Femoral (1) & Distal (1) & 53296 & 3 & 0.06 & - & 0.06 & 0.06 & 0.06 \\
\hline Cardiac & All & 41 & $\begin{array}{l}\text { Femoral (7) } \\
\text { Radial (34) }\end{array}$ & Distal (41) & 35841 & 4 & 0.18 & 0.30 & 0.11 & $\leqslant 0.02$ & 1.98 \\
\hline Thoracic & All & 5 & $\begin{array}{c}\text { Femoral (1) } \\
\text { Humeral (1) } \\
\text { IJV (2) } \\
\text { Radial (1) }\end{array}$ & Distal (5) & 91640 & 5 & 0.35 & 0.40 & 0.13 & 0.07 & 0.99 \\
\hline $\begin{array}{l}\text { Upper- } \\
\text { extremity }\end{array}$ & All & 4 & $\begin{array}{c}\text { Femoral (1) } \\
\text { Radial (2) } \\
\text { Direct (1) }\end{array}$ & $\begin{array}{l}\text { Distal (1) } \\
\text { Close (3) }\end{array}$ & 55835 & 2 & 0.40 & 0.25 & 0.47 & 0.05 & 0.61 \\
\hline Abdominal & All & 18 & $\begin{array}{c}\text { Femoral (7) } \\
\text { IJV (9) } \\
\text { Direct (2) }\end{array}$ & $\begin{array}{c}\text { Distal (14) } \\
\text { Close (4) }\end{array}$ & 47453 & 5 & 0.18 & 0.36 & 0.06 & $\leqslant 0.02$ & 1.59 \\
\hline Pelvic & All & 1 & Femoral (1) & Close (1) & - & 1 & 0.34 & - & 0.34 & 0.34 & 0.34 \\
\hline $\begin{array}{l}\text { Lower- } \\
\text { extremity }\end{array}$ & All & 7 & Femoral & $\begin{array}{l}\text { Distal (3) } \\
\text { Close (3) }\end{array}$ & 57827 & 4 & 0.27 & 0.26 & 0.18 & 0.04 & 0.69 \\
\hline $\begin{array}{l}\text { Bone } \\
\text { and joint }\end{array}$ & All & 7 & $\begin{array}{c}\text { Femoral (2) } \\
\text { Direct (5) }\end{array}$ & $\begin{array}{l}\text { Distal (2) } \\
\text { Close (5) }\end{array}$ & 150097 & 11 & 0.48 & 0.73 & 0.05 & 0.02 & 1.81 \\
\hline
\end{tabular}

\subsubsection{Effect of procedure class}

Table 2 documents finger doses as a function of procedure class and shows that the lowest doses are for Cerebral procedures $(0.02 \mathrm{mSv}$, close to the LDL), since the femoral access route is mostly used during such procedures. This is in agreement with the data $($ mean $=0.019 \mathrm{mSv})$ reported by Stern et al. (1995). Similar mean finger dose values were also found for Transjugular Intrahepatic Portosystemic Shunts - TIPS (Whitby and Martin, 2005), for biliary drainage and stenting (Whitby and Martin, 2005; Blanpain et al., 2008) and for hepatic chemoembolization (Whitby and Martin, 2005; Carinou et al., 2011). This is also true for vertebroplasty (Harstall et al., 2005; Synowitz and Kiwit, 2006, etc.) and for coronarography and coronary angioplasty (Kim et al., 2008; Donadille et al., 2011). However, for pacemaker and defibrillator implantation, the mean finger doses reported here are smaller than those reported by Kim et al. (2008) and Donadille et al. (2011).

\subsubsection{Effect of access route}

To check the influence of the access route on the finger dose, the procedures were split into Cardiac (using radial and femoral access routes) and non-Cardiac (using direct, internal jugular vein (IJV) and femoral access routes). In Cardiac procedures, the radial access route was found to be significantly more irradiating $(n=49,0.12 \mathrm{mSv})$ than the femoral access route $(n=14,0.05 \mathrm{mSv})$. In non-Cardiac procedures, the direct access route $(n=72,0.25 \mathrm{mSv})$ was significantly more irradiating than both the femoral $(n=160,0.17 \mathrm{mSv})$ and the IJV routes $(n=20,0.08 \mathrm{mSv})$. These results are in agreement with Whitby and Martin (2005) and Martin (2009). Finally, no significant difference was observed between the IJV $(n=20$, $0.08 \mathrm{mSv})$ and the femoral access routes $(n=160,0.17 \mathrm{mSv})$.

\subsubsection{Effect of protective equipment}

The use of a ceiling-suspended shield in close procedures ( $n=22,0.15 \mathrm{mSv}$ ) was found to significantly reduce finger doses when compared with procedures without a shield $(n=52,0.33 \mathrm{mSv})$; whereas, for distal procedures, no significant difference could be established since the median doses with $(n=94)$ and without $(n=82)$ a shield are the same $(0.10 \mathrm{mSv})$. As a conclusion, the apparent effect on hand doses of a ceiling-suspended shield is difficult to determine and, if any effect is found, it is well below the theoretical attenuation factors of such screens, which typically range between 100 and 10 for $70-100 \mathrm{kV}$ medical X-ray fields, respectively. This may be due to the fact that, during the procedure, hands may frequently lie in unprotected positions (below or to the side of the screen) and the protection strongly depends on the correct positioning of the screen. This observation is in agreement with previous work (Whitby and Martin, 2005; Donadille et al., 2011) and the arguments given explaining the results obtained were also used by Koukorava et al. (2011).

Meanwhile, leaded gloves were only used in 27 procedures out of 346 and, in this case, no significant difference could be statistically demonstrated between the doses for procedures with or without leaded gloves. This is true even though a factor of 2 was observed on the registered doses with $(n=27$, $0.07 \mathrm{mSv}$ ) or without leaded gloves $(n=319,0.14 \mathrm{mSv})$. Moreover, even when limiting the comparison to the Bone 


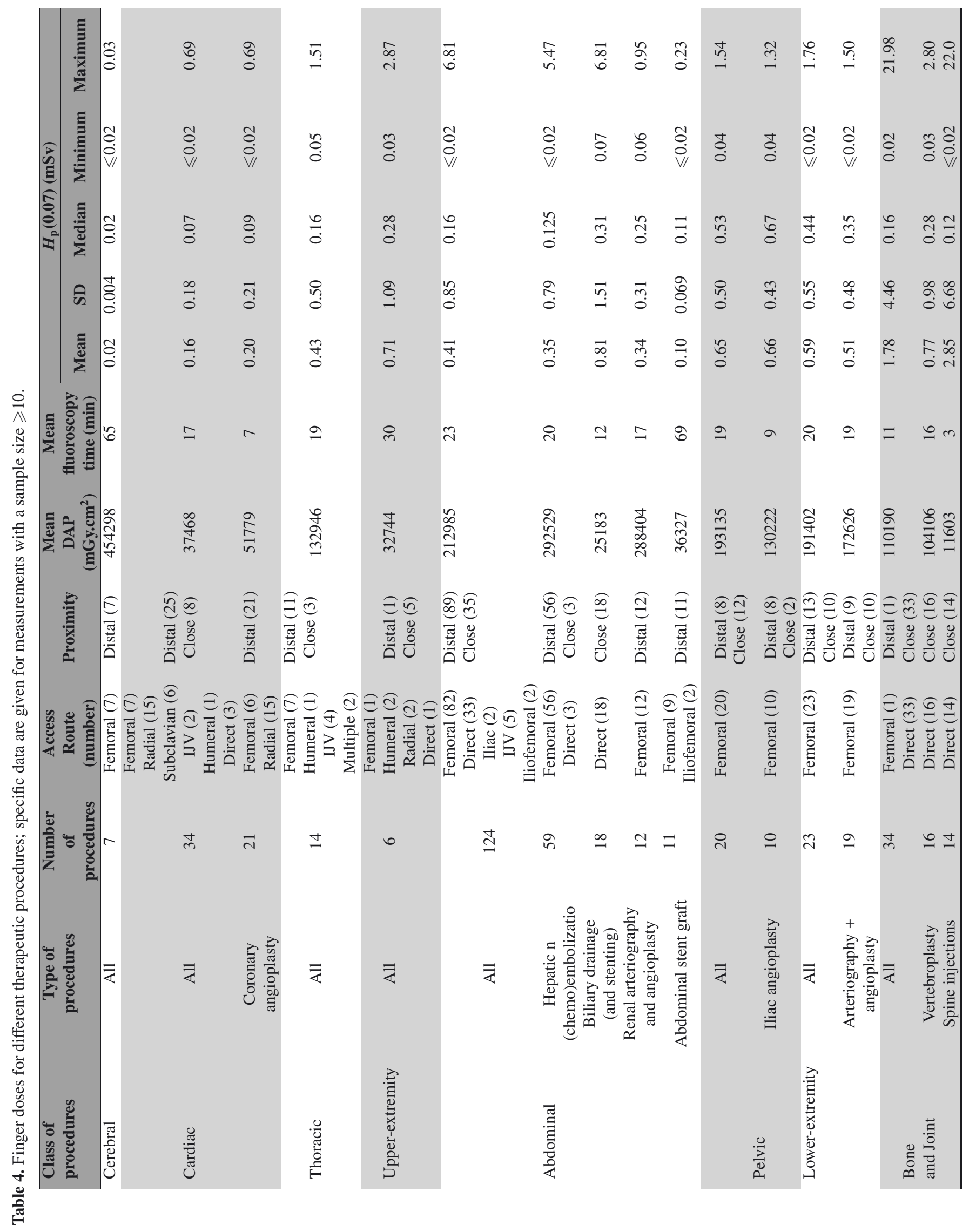


Table 5. Results of the statistical tests for the comparison of finger doses among different classes of procedures (median values are given in parentheses).

\begin{tabular}{|c|c|c|c|c|c|c|c|c|}
\hline & $\begin{array}{c}\text { Cerebral } \\
(0.02 \mathrm{mSv})\end{array}$ & $\begin{array}{c}\text { Cardiac } \\
(0.09 \mathrm{mSv})\end{array}$ & $\begin{array}{l}\text { Thoracic } \\
(0.16 \mathrm{mSv})\end{array}$ & $\begin{array}{c}\text { Upper-extremity } \\
(0.36 \mathrm{mSv})\end{array}$ & $\begin{array}{l}\text { Abdominal } \\
(0.14 \mathrm{mSv})\end{array}$ & $\begin{array}{c}\text { Pelvic } \\
(0.45 \mathrm{mSv})\end{array}$ & $\begin{array}{c}\text { Lower-extremity } \\
(0.30 \mathrm{mSv})\end{array}$ & $\begin{array}{c}\text { Bone and Joint } \\
(0.13 \mathrm{mSv})\end{array}$ \\
\hline $\begin{array}{l}\text { Cerebral } \\
(0.02 \mathrm{mSv})\end{array}$ & & $s<$ & $s<$ & $s<$ & $s<$ & $s<$ & $s<$ & $s<$ \\
\hline $\begin{array}{l}\text { Cardiac } \\
(0.09 \mathrm{mSv})\end{array}$ & $s>$ & & $s<$ & $s<$ & $s<$ & $s<$ & $s<$ & $s d$ \\
\hline $\begin{array}{l}\text { Thoracic } \\
(0.16 \mathrm{mSv})\end{array}$ & $s>$ & $s>$ & & $n s d$ & $n s d$ & $n s d$ & $n s d$ & $n s d$ \\
\hline $\begin{array}{l}\text { Upper-extremity } \\
(0.36 \mathrm{mSv})\end{array}$ & $s>$ & $s>$ & $n s d$ & & $n s d$ & $n s d$ & $n s d$ & nsd \\
\hline $\begin{array}{l}\text { Abdominal } \\
(0.14 \mathrm{mSv})\end{array}$ & $s>$ & $s>$ & $n s d$ & $n s d$ & & $s<$ & $s<$ & $n s d$ \\
\hline $\begin{array}{l}\text { Pelvic } \\
(0.45 \mathrm{mSv})\end{array}$ & $s>$ & $s>$ & $n s d$ & $n s d$ & $s>$ & & $n s d$ & $n s d$ \\
\hline $\begin{array}{l}\text { Lower-extremity } \\
(0.30 \mathrm{mSv})\end{array}$ & $s>$ & $s>$ & $n s d$ & $n s d$ & $s>$ & nsd & & $n s d$ \\
\hline $\begin{array}{l}\text { Bone and Joint } \\
(0.13 \mathrm{mSv})\end{array}$ & $s>$ & $s d$ & $n s d$ & $n s d$ & $n s d$ & $n s d$ & $n s d$ & \\
\hline
\end{tabular}

and Joint class in which leaded gloves were most frequently used, no statistically significant difference between the doses with $(n=21,0.07 \mathrm{mSv})$ and without leaded gloves $(n=20$, $0.26 \mathrm{mSv}$ ) was observed. As a conclusion, the dose reduction offered by leaded gloves could not be demonstrated and could be explained by the fact that wearing gloves is cumbersome and results in the loss of dexterity which increases the operation time, and in consequence, hand exposure. The poor protection efficiency of leaded gloves was also observed by Martin and Whitby (2003).

\subsubsection{Effect of tube orientation}

Two configurations were investigated for which the tube is either above (over-couch) or below (under-couch) the horizontal plane defined by the couch. No significant difference in the doses could be established among the procedures with the over-couch tube configuration $(n=12,0.30 \mathrm{mSv})$. Similar results were noted for the under-couch tube configuration $(n=334,0.14 \mathrm{mSv})$ although the medians are different by a factor of 2. Moreover, even when limiting the comparison to the Bone and Joint class, in which the under-couch configuration was used most frequently, no significant difference could be observed between the doses associated with the over-couch tube $(n=10,0.80 \mathrm{mSv})$ and those with the under-couch one $(n=31,0.11 \mathrm{mSv})$.

\subsection{Statistical analysis and dose scale classification}

The comparison of the finger doses received by operators for different classes of procedures is presented in Table 5 along with the median dose value for each class, since mainly the WRS test could only be applied due to the different sizes of classes. In Table 5 each row entry is compared with a column entry: the dose for a given class (row) is either significantly $(p<0.05)$ greater $(s>)$, or lower $(s<)$, or different $(s d)$ than the dose for another class (column), or both classes are not significantly $(p>0.05)$ different $(n s d)$. According to the WRS test, the median finger dose of the Cerebral class is significantly lower than that of all the other classes, and so is the median finger dose of the Cardiac class, except compared with the Cerebral class and with the Bone and Joint class, with which a significant difference could only be demonstrated. Consequently, only the Cerebral and Cardiac columns/rows are set apart in a significant manner from each other and from the other classes of procedures. The observed results can be rationally explained by the fact that some procedures included in the latter group (i.e. Abdominal, Pelvic, etc.) involve long fluoroscopy times (e.g. TIPS) and are often close procedures (e.g. biliary drainage, Bone and Joint class).

Based on these results, a dose scale classification was proposed ( $c f$. Tab. 6). For different comparison criteria (type, proximity, class and access route of the procedure) only subgroups for which the finger doses are significantly different are shown. The subgroups are classified according to three intervals using a relative dose index: ' + ', ' ++ ' and ' +++ ' for a mean dose per procedure $<0.2 \mathrm{mSv}$, from $0.2-0.5 \mathrm{mSv}$ and $\geqslant 0.5 \mathrm{mSv}$, respectively. In addition, in each case the mean and SD of the finger dose distribution are given as well as the deduced estimated maximum number of procedures (and its statistical uncertainty) that can be performed to reach $3 / 10$ th $(150 \mathrm{mSv})$ of the annual $500 \mathrm{mSv}$ limit (ICRP, 2007) (ratio between $150 \mathrm{mSv}$ and the mean dose). Beyond this limit, a physician should be classified as a category A worker and hand monitoring should be set up according to Council Directive 96/29/Euratom (1996). Moreover, from this classification, it is possible to compare finger doses for different operators or specialties. For instance, an operator performing Cerebral procedures is expected to receive a lower finger dose than cardiologists and others, whereas a cardiologist frequently using the radial access route is expected to receive higher finger doses than another performing a similar Cardiac procedure through the femoral artery. Particular attention should be given to therapeutic, close procedures with a direct (percutaneous) access, 
Table 6. Finger dose classification for different criteria (type, proximity, class and access route of the procedure) and subgroups (diagnostic vs. therapeutic, distal vs. close, etc.).

\begin{tabular}{|c|c|c|c|c|c|c|c|}
\hline Type & $\begin{array}{c}\text { Subgroup } \\
\text { Mean (SD) [mSv] } \\
\mathrm{N} \pm \text { unc. } \\
\text { Dose index }\end{array}$ & $\begin{array}{c}\text { Diagnostic } \\
0.32(0.80) \\
468 \pm 124 \\
++\end{array}$ & $\begin{array}{c}\text { Therapeutic } \\
0.56(1.7) \\
267 \pm 50 \\
+++\end{array}$ & & & & \\
\hline Proximity & $\begin{array}{c}\text { Subgroup } \\
\text { Mean (SD) }[\mathrm{mSv}] \\
\mathrm{N} \pm \text { unc. } \\
\text { Dose index }\end{array}$ & $\begin{array}{c}\text { Distal } \\
0.29(0.51) \\
517 \pm 60 \\
++\end{array}$ & $\begin{array}{c}\text { Close } \\
0.92(2.5) \\
163 \pm 41 \\
+++\end{array}$ & & & & \\
\hline Class & $\begin{array}{c}\text { Subgroup } \\
\text { Mean (SD) }[\mathrm{mSv}] \\
\mathrm{N} \pm \text { unc. } \\
\text { Dose index }\end{array}$ & $\begin{array}{c}\text { Cerebral } \\
0.03(0.01) \\
5000 \pm 589 \\
+\end{array}$ & \multicolumn{2}{|c|}{$\begin{array}{c}\text { Cardiac } \\
0.17(0.26) \\
882 \pm 156 \\
+\end{array}$} & \multicolumn{3}{|c|}{$\begin{array}{l}\text { Others } \\
0.61(1.8) \\
245 \pm 45 \\
+++\end{array}$} \\
\hline Access & $\begin{array}{c}\text { Subgroup } \\
\text { Mean (SD) }[\mathrm{mSv}] \\
\mathrm{N} \pm \text { unc. } \\
\text { Dose index }\end{array}$ & & $\begin{array}{c}\text { Femoral } \\
0.09(0.09) \\
1667 \pm 446 \\
+\end{array}$ & $\begin{array}{c}\text { Radial } \\
0.22(0.31) \\
681 \pm 139 \\
++\end{array}$ & $\begin{array}{c}\text { IJV } \\
0.26(0.40) \\
576 \pm 198 \\
++\end{array}$ & $\begin{array}{c}\text { Femoral } \\
0.34(0.45) \\
441 \pm 45 \\
++\end{array}$ & $\begin{array}{c}\text { Direct } \\
1.2(3.2) \\
125 \pm 39 \\
+++\end{array}$ \\
\hline
\end{tabular}

especially if they belong to the Thoracic, Upper-extremity, Abdominal, Pelvic, Lower-extremity, or Bone and Joint class of procedures. For an attainable number of procedures per year (say around 200), the annual dose tends to $150 \mathrm{mSv}$ in the case of therapeutic, close and direct access procedures.

\section{Conclusion}

A statistical analysis of finger dose measurements for operators performing interventional procedures, acquired within the ORAMED project, was conducted to classify the procedures by dose scale and investigate the factors most influencing the dose. The originality of this work lies in assessing the relative uncertainty of dose measurement based on statistical analysis applied to the acquired data. The paper thus provides finger doses while separately considering 8 classes of procedures as well as specific procedure types. Namely, the main operator's highest $(1.56 \mathrm{mSv})$ and lowest $(0.03 \mathrm{mSv})$ skin dose equivalent, $\mathrm{Hp}(0.07)$, was, respectively, received for Bone and Joint, and Cerebral procedures. Moreover, Cerebral procedures were found to be less irradiating than Cardiac ones, which are less irradiating than the other ones (i.e. Thoracic, Pelvic, etc.). Meanwhile, the registered finger dose in therapeutic procedures and in close ones was significantly greater than the dose in diagnostic procedures and in distal ones, respectively. The effect of a ceiling-suspended shield was statistically significant for close procedures only, while no significant reduction of the dose by leaded gloves was observed. Finally, no significant correlation was found between the finger dose and the fluoroscopy time; a low but significant correlation was, however, found with the Dose-Area Product. Hence, and although multiple authors (LeHeron, 1992; Stern et al., 1995) promote risk assessment based on DAP values, the results of this study indicate that such processing should be considered with care.

In this work, operators' finger doses were measured for 60 different procedures under the same study design while, in the literature, the focus is often on one particular procedure. Nonetheless, a general good agreement was obtained when comparing the doses registered here and published data.
This proves that practitioners are exposed to similar dose levels even though sensitive differences may exist regarding the methods, training and experience, etc. Finally, from the set of collected and analyzed data, a finger dose classification was proposed for different criteria: type (diagnostics/therapeutic), proximity (close/distal), class and access route. This classification can be used by the radiation protection personnel (employer, occupational medical practitioner, qualified expert, etc.) as well as by the physicians themselves to acknowledge potential hand exposure levels and thus prioritize radiation protection actions, i.e. local dose assessment, optimization, individual monitoring, worker classification and medical surveillance.

Acknowledgements. The authors would like to acknowledge all those who participated in the measurement campaign at: the University Hospital Center (CHU) of Clermont Ferrand, the CHU of Grenoble, the Regional CHU of Lille, Beaujon Hospital (Clichy), Paul Brousse Hospital (Villejuif), Cochin Hospital (Paris), Antoine Béclère Hospital (Clamart) and la Pitié Salpêtrière Hospital (Paris). The study was conducted under the auspices of the Interuniversity Institute of Occupational Medicine of Paris Ile-de-France (IIMTPIF).

\section{References}

Blanpain T., Brasselet C., Tassan-Mangina S., Deschildre A., Clément J.P., Gaillot-Petit N., Tourneux C., Metz D. (2008) Doses estimations of a comparative study between radial and femoral access during coronary angiograms and percutaneous coronary interventions, Radioprotection 43, 449-463.

Carinou E., Brodecki M., Domienik J., Donadille L., Koukorava C., Krim S., Nikodemová D., Ruiz-Lopez N., Sans-Merce M., Struelens L., Vanhavere F. (2011) Recommendations to reduce extremity and eye lens doses in interventional radiology and cardiology, Radiat. Meas. 46, 1324-1329.

Council Directive 96/29/Euratom of 13 May 1996 laying down basic safety standards for the protection of the health of workers and the general public against the dangers arising from ionizing radiation, Official Journal L 159, 1-114. 
Delichas M., Psarrakos K., Molyvda-Athanassopoulou E., Giannoglou G., Sioundas A., Hatziioannou K., Papanastassiou E. (2003) Radiation exposure to cardiologists performing interventional cardiology procedures, Eur. J. Radiol. 48, 268-273.

Donadille L., Carinou E., Brodecki M., Domienik J., Jankowski J., Koukorava C., Krim S., Nikodemova D., Ruiz-Lopez N., SansMerce M., Struelens L., Vanhavered F., Zaknoune R. (2011) Staff eye lens and extremity exposure in interventional cardiology: results of the ORAMED project, Radiat. Meas. 46, 1203-1209.

Efstathopoulos E.P., Pantos I., Andreou M., Gkatzis A., Carinou E., Koukorava C., Kelekis N.L., Brountzo E. (2011) Occupational radiation doses to the extremities and the eyes in interventional radiology and cardiology procedures, Br. J. Radiol. 84, 70-77.

Fay M.P., Proschan M.A. (2010) Wilcoxon-Mann-Whitney or t-test? On assumptions for hypothesis tests and multiple interpretations of decision rules, Stat. Surveys 4, 1-39.

Harstall R., Heine P.F., Mini R.L., Orler R. (2005) Radiation exposure to the surgeon during fluoroscopically assisted percutaneous vertebroplasty, Spine 16, 1893-1898.

ICRP Publication 74 (1997) Conversion coefficients for use in radiological protection against external radiation, Ann. ICRP 26.

ICRP Publication 103 (2007) The 2007 Recommendations of the International Commission on Radiological Protection, Ann. ICRP 37.

ISO 4037-1 (1996) X and gamma reference radiation for calibrating dosimeters and dose-rate meters and determining their response as a function of photon energy - Part 1: Radiation characteristics and production methods.

ISO 4037-2 (1997) $\mathrm{X}$ and gamma reference radiation for calibrating dosimeters and dose-rate meters and determining their response as a function of photon energy - Part 2: Dosimetry for radiation protection over the energy range $8 \mathrm{keV}$ to $1.3 \mathrm{MeV}$ and $4 \mathrm{MeV}$ to $9 \mathrm{MeV}$.

ISO 4037-3 (1999) $\mathrm{X}$ and gamma reference radiation for calibrating dosimeters and dose-rate meters and determining their response as a function of photon energy - Part 3: Calibration of area and personal dosimeters and the measurement of their response as a function of energy and angle of incidence.

Kim K.P., Miller D.L., Balter S., Kleinerman R.A., Linet M.S., Kwon D., Simon S.L. (2008) Occupational radiation doses to operators performing cardiac catheterization procedures, Health Phys. 94, 211-227.

Kim K.P., Miller D. (2009) Minimising radiation exposure to physicians performing fluoroscopically guided cardiac catheterisation procedures: A review, Radiat. Prot. Dosim. 133, 227-233.

Koukorava C., Carinou E., Ferrari P., Krim S., Struelens L. (2011) Study of the parameters affecting operator doses in interventional radiology using Monte Carlo simulations, Radiat. Meas. 46, 1216-1222.

LeHeron J.C. (1992) Estimation of effective dose to the patient during medical X-ray examinations from measurements of dose-area product, Phys. Med. Biol. 37, 2117-2126.
Marshall N.W., Noble J., Faulkner K. (1995) Patient and staff dosimetry in neuroradiological procedures, Br. J. Radiol. 68, 495-501.

Martin C.J. (2009) A review of radiology staff doses and dose monitoring requirements, Radiat. Prot. Dosim. 136, 140-157.

Martin C.J., Whitby M. (2003) Application of ALARP to extremity doses for hospital workers, J. Radiol. Prot. 23, 405-421.

Miller D.L. (2008) Overview of contemporary interventional fluoroscopy procedures, Health Phys. 95, 638-644.

Miller D.L., Vañó E., Bartal G., Balter S., Dixon R., Padovani R., Schueler B., Cardella J.F., de Baère T. (2010) Occupational radiation protection in interventional radiology: a joint guideline of the Cardiovascular and Interventional Radiology Society of Europe and the Society of Interventional Radiology, Cardiovasc. Intervent. Radiol. 33, 230-239.

Pappas P.A., DePuy V. (2004) An overview of non-parametric tests in SAS ${ }^{\circledR}$ : When, Why, and How. In: The Proceedings of the South-East SAS Users Group, SESUG 2004, Nashville, TN, paper TU04:1-5.

Ramsdale M.L., Walker W.J., Horton P.W. (1990) Extremity doses during interventional radiology, Clin. Radiol. 41, 34-36.

Roger V.L. et al. (2011) Heart Disease and Stroke Statistics 2011 Update. A Report from the American Heart Association, Citation 11 123, e18-e209.

SAS Institute Inc. (1999) The SAS (Statistical Analysis Systems, Institute Inc.) System Release 8.02, Cary, NC, USA.

Stern S.H., Rosenstein M., Renaud L., Zankl M. (1995) Handbook of selected tissue doses for fluoroscopic and cineangiographic examination of coronary arteries. HHS Publication FDA 95-8289. Rockville, MD: US Department of Health and Human Services.

Synowitz M., Kiwit J. (2006) Surgeon's radiation exposure during percutaneous vertebroplasty, J. Neurosurg. Spine 4, 106-109.

Togni M., Balmer F., Pfiffner D., Maier W., Zeiher A.M., Meier B. (2004) Percutaneous coronary interventions in Europe 1992-2001, Eur. Heart J. 25, 1208-1213.

UNSCEAR (2008) Sources and Effects of Ionizing Radiation, Volume I: Sources. Report to the General Assembly with Scientific Annexes A and B. United Nations, Vienna.

Vanhavere F. et al. (2012) ORAMED: Optimization of Radiation Protection of Medical Staff. EURADOS Report 2012-02, ISSN 2226-8057.

Vaňo E., Fernandez J.M., Delgado V., González L. (1995) Evaluation of tungsten and lead surgical gloves for radiation protection, Health Phys. 68, 855-858.

Watson L.E., Riggs M.W., Bourland P.D. (1997) Radiation exposure during cardiology fellowship training, Health Phys. 73, 690-693.

Whitby M., Martin C.J. (2005) A study of the distribution of dose across the hands of interventional radiologists and cardiologists, Br. J. Radiol. 78, 219-229. 